\title{
Wood smoke exposure of Portuguese wildland firefighters: DNA and oxidative damage evaluation
}

\author{
Ana Abreu, Carla Costa, Susana Pinho e Silva, Simone Morais, Maria do \\ Carmo Pereira, Adília Fernandes, Vanessa Moraes de Andrade, João Paulo \\ Teixeira \& Solange Costa
}

To cite this article: Ana Abreu, Carla Costa, Susana Pinho e Silva, Simone Morais, Maria do Carmo Pereira, Adília Fernandes, Vanessa Moraes de Andrade, João Paulo Teixeira \& Solange Costa (2017) Wood smoke exposure of Portuguese wildland firefighters: DNA and oxidative damage evaluation, Journal of Toxicology and Environmental Health, Part A, 80:13-15, 596-604, DOI: $10.1080 / 15287394.2017 .1286896$

To link to this article: https://doi.org/10.1080/15287394.2017.1286896

\section{Published online: 19 May 2017.}

Submit your article to this journal

Џlll Article views: 152

Q View related articles 주

View Crossmark data $ک$ 


\title{
Wood smoke exposure of Portuguese wildland firefighters: DNA and oxidative damage evaluation
}

\begin{abstract}
Ana Abreu ${ }^{\mathrm{a}, \mathrm{b}}$, Carla Costa ${ }^{\mathrm{a}, \mathrm{b}}$, Susana Pinho e Silva ${ }^{\mathrm{b}}$, Simone Morais ${ }^{\mathrm{c}}$, Maria do Carmo Pereira ${ }^{\mathrm{d}}$, Adília Fernandes Vanessa Moraes de Andrade $\mathbb{1}^{\mathrm{f}}$, João Paulo Teixeira ${ }^{\mathrm{a}, \mathrm{b}}$, and Solange Costa ${ }^{\mathrm{a}, \mathrm{b}}$

aEPIUnit-Instituto de Saúde Pública, Universidade do Porto, Porto, Portugal; bEnvironmental Health Department, National Institute of Health, Environmental Health Department, Porto, Portugal; 'REQUIMTE/LAQV, Instituto Superior de Engenharia do Instituto Politécnico do Porto Rua Dr. António Bernardino de Almeida, Porto, Portugal; 'LEPABE, Department of Chemical Engineering, Faculty of Engineering of the University of Porto Rua Dr. Roberto Frias,Porto, Portugal; 'Escola Superior de Saúde, Instituto Politécnico de Bragança, Avenida D. Afonso V, Bragança, Portugal; fLaboatory of Molecular and Cellular Biology Graduate Programme of Health Sciences, Health Sciences Unit, University of Southern Santa Catarina, UNESC, Santa Catarina, Brazil
\end{abstract}

\begin{abstract}
Portugal is among the European Union countries most devastated by forest fires each year. In the last three decades, more than 3.8 million hectares of forest were burned. Wildland firefighters are exposed to a variety of hazards, including many toxic combustion products that may lead to deleterious health effects. Epidemiological studies showed a positive association between firefighting and several chronic diseases, including cancer. Results from biomonitoring studies in firefighters, particularly concerning genotoxicity evaluation, constitute a valuable tool for investigating important occupational hazards. Thus, the aim of this study was to assess genotoxicity in a group of wildland firefighters using the comet assay for DNA damage and oxidative stress. Both parameters were increased in firefighters compared to controls, but significance was only found for basal DNA damage. No significant influence was found regarding major confounding variables on the genotoxic endpoints studied, with the exception of age. Data obtained provide preliminary information on human health effects of wildland firefighting exposure at genetic and molecular levels. These findings may also provide new important data to serve as public awareness to the potential adverse health risks involving wildland firefighting. Implementation of security and hygiene measures in this sector as well as good practices campaigns may be crucial to decrease risk.
\end{abstract}

\section{Introduction}

During Portuguese summer season characterized by hot and dry weather, the wildland is frequently devastated by violent fires. For the last three decades, 3.8 million hectares of Portuguese forest were consumed (Schmuck et al., 2014), and the total forest area of the country is 3.2 million hectares (ICNF, 2013). Regarding Europe, in 2013 alone, Portuguese burned forest accounted for more than $50 \%$ of the burned area of the five southern European countries combined, Spain, France, Italy, Portugal, and Greece (Pereira et al., 2014).

The main line of defense against wildland fires is firefighters. Portuguese wildland firefighting is supported by a human force of 30000 firefighters, both volunteer and professionals (INE, 2015). The continuous work of these individuals in dangerous environments has raised concerns regarding health consequences. Smoke exposure is one of the most overlooked, yet important hazard encountered by firefighters during their activities (Austin et al., 2001; Leonard et al., 2007; Golka \& Weistenhofer, 2008).

There is a general agreement on the importance of wood smoke on human health (Zelikoff et al., 2002; Miranda et al., 2010). Wildland fire smoke is a complex mixture of numerous gaseous and particulate pollutants that interacts with the surrounding environment (IARC, 2010; Miranda et al., 2012). Compounds present in smoke comprise carbon monoxide, aldehydes, benzene, formaldehyde, benzopyrene and particulate matter (PM) among many others (Austin et al., 2001; Naeher et al., 2007; Golka \& Weistenhofer, 2008; 
Oliveira et al., 2016). Many of these pollutants are known to produce adverse health effects (Durán et al., 2014; Elliott, 2014).

Firefighters constitute a population of particular interest due to the intermittent nature of their exposure and general work conditions. During wildland firefighting activities, these individuals have an enormous work load sometimes working for several days and in physical demanding conditions and locations (Budd et al., 1997; Ruby et al., 2002). In Portugal, the use of personal protective equipment (PPE) for wildland firefighting is regulated (Order no. 3974/2013; Order no. 4958/2014) and includes a structural helmet with eye protection, complete mask (with filter for particulate matter), flash hood, gloves, boots and fire resistant clothing. Nevertheless, during wildland forest fires, there may be a general misuse of masks since these add increased physiological demands and heat stress upon the user. The use of masks also increases the effort for communication and desire to conserve air (IARC, 2010) which may explain the lack of proper use.

The predominant symptoms reported by firefighters, immediately or a few hr after exposure, are eye and respiratory irritation as well as shortness of breath that develops into headaches, dizziness, and nausea (Reinhardt \& Ottmar, 2000). Long-term adverse health effects noted in several epidemiological studies include an elevated risk of cardiovascular diseases (Fahy, 2005; Fahs et al., 2011), cancer (Golka \& Weistenhofer, 2008) and respiratory impairments (Slaughter et al., 2004; Gaughan et al., 2008; Swiston et al., 2008). Further, several smoke compounds are classified by the International Agency for Research in Cancer (IARC) as known (Group 1) or probable (Group 2B) human carcinogens (IARC, 2010). Some of Group 1 agents include benzene, vinyl chloride, formaldehyde and PM with diameter below $2.5 \mu \mathrm{m}$; Group 2B comprises black carbon and ethylbenzene (Melius, 2000; Stefanidou et al., 2008).

Several in vitro experiments using human cell lines demonstrated the ability of wood smoke extract and derived components, namely PM to induce oxidative stress (Adetona et al., 2016). In general, an increase in lipid peroxidation (Leonard et al., 2000), production of free radicals, DNA damage levels (Corsini et al., 2013), and oxidized base levels (Danielsen et al., 2009) was found.
Upregulation of antioxidant enzymes such as heme oxygenase (HO-1) and superoxide dismutase (Cu/Zn SOD) (Lee et al., 2008, Danielsen et al., 2011) and depletion of endogenous antioxidant capacity, namely reduction in glutathione (GSH) (Liu et al., 2005) were also reported. In animal models, after exposure to wood smoke, elevated levels of thiobabituric acid reactive substances (TBARS) were found in plasma and lung tissue of male sheep (Park et al., 2004) and lung tissue of rats (Dubick et al., 2002). Ramos et al (2013) noted that short-term exposure to wood smoke in guinea pigs induced alterations in oxidative/antioxidant state and lung injury.

The majority of biomonitoring studies examining adverse of wood smoke exposure in humans focused on systemic inflammation biomarkers and impact on cardio-respiratory indicators (Naeher et al., 2007; Hejl et al., 2013), but few investigators assessed genotoxicity biomarkers. However, data are available on oxidative damage to DNA (Gaughan et al., 2014; Jensen et al., 2014) and to lipids (Barregard et al., 2008). Results are not as consistent as those reported for in vitro and in vivo studies. The limited number of investigations and varying scenarios of exposure evaluated such as controlled exposure trials, household, and occupational settings may have contributed to the diversity of findings.

Biomonitoring is any measurement reflecting an interaction between a biological system and an environmental agent, which may be chemical, physical, or biological (Oliveira et al., 2014). Biomonitoring provides an integrated measure of the level of exposure to chemicals through different pathways and exposure routes (Ahlborg et al., 1994; Cooke, 2014). Biomarkers of effect demonstrate the body's response to exposure and may be indicative of early subclinical changes, which if sustained, may lead to pathological consequences (Links et al., 1995). Genotoxicity evaluation constitutes a valuable tool for studying important occupational hazards (Campos et al., 2016). The comet assay or single gel electrophoresis is a valuable effect biomarker that quantifies DNA damage in populations exposed to various types of agents (Collins et al., 2014). This method (1) is highly sensitive concomitant with its simplicity and low cost, (2) offers more advantages 
than the classical cytogenetic assays, and (3) is probably one of the most used assays for the assessment of DNA damage and repair (Neri et al., 2015). Comet assay sensitivity might also be enhanced to measure a wide range of DNA lesions such as those resulting in oxidative damage by the introduction of lesion specific repair enzymes (Collins, 2004). The lesions detected by the classical alkaline comet assay may be due to either oxidative or non-oxidative DNA damage, while the measurement of enzymespecific sites resulting from the activity of baseoxidized repair enzymes such as formamidopyrimidine DNA glycosylase (FPG) is considered to be more specific toward dertermination of oxidative DNA damage (Danielsen et al., 2009).

For most of the human genotoxicity assays, lymphocytes are the preferred cells since these are sentinel cells that may inform regarding events occurring in target tissues (Costa et al., 2015). However, the use of whole blood as a viable and easier alternative in comet assay was recently employed by several investigators (Al-Salmani et al., 2011; Akor-Dewu et al., 2014). The main advantages presented are avoidance of additional DNA damage from lymphocyte-isolation steps and loss of cells (Al-Salmani et al., 2011; Collins et al., 2014). In this context, the aim of the present study was to assess in whole blood of Portuguese wildland firefighters whether DNA damage and oxidative stress occurred.

\section{Material and methods}

\section{Study population}

General characteristics of the studied population are summarized in Table 1 . In total, 123 subjects were involved in the study, 60 volunteer firefighters from 12 fire departments located in the North of Portugal with at least one-year experience, and 63 non-exposed control subjects, matched by age, gender and smoking habits, working in administrative offices. For each subject, health conditions, general medical history, and relevant individual information were assessed by means of self-administered questionnaire. Since the number of exsmokers (subjects that stop smoking for at least 2
Table 1. General Characteristics of the Study Population.

\begin{tabular}{|c|c|c|c|c|}
\hline Respiratory pathology & 63 & & 60 & \\
\hline Yes & & $2(3.2 \%)$ & & $7(11.7 \%)$ \\
\hline No & & $61(96.8 \%)$ & & $53(88.3 \%)$ \\
\hline Allergies & 63 & & 60 & \\
\hline Yes & & 11 (17.5\%) & & $3(5.0 \%)$ \\
\hline No & & $52(82.5 \%)$ & & $57(95.0 \%)$ \\
\hline Medication intake & 63 & & 60 & \\
\hline Yes & & $21(33.3 \%)$ & & $9(15.0 \%)$ \\
\hline No & & 42 (66.7\%) & & 51 (85.0\%) \\
\hline Years of activity ${ }^{a}$ & & - & & $12.60 \pm 8.2$ \\
\hline Recent exposure (hours) ${ }^{a}$ & & - & & $1.92 \pm 2.67$ \\
\hline
\end{tabular}

years) was low ( $\mathrm{n}=4)$, two smoking habit groups were established as non-smokers and smokers.

Only subjects with no history of chronic disease and no history of occupational exposure to known carcinogens were selected for this study. Firefighters also provided information related to working practices, namely years of employment and hr of recent exposure. Information related to use of personal protective equipment (PPE) among firefighters was also questioned. All participants were fully informed regarding the aim of this investigation, and an informed consent was signed. Ethical approval was obtained from the Ethical Board of the National Institute of Health Doutor Ricardo Jorge.

\section{Blood sample collection}

Venous blood samples were collected from each subject in ethylenediamine tetra-acetic acid (EDTA) containing tubes between June and August of 2014. After collection samples were coded and processed under blinded conditions, samples were suspended in cryopreservation medium of DMSO:RPMI $(1: 4, \mathrm{v} / \mathrm{v})$ and frozen at $-80^{\circ}$ $\mathrm{C}$ until transportation on dry-ice (1-2 h) for comet assay procedure. Before the assay, the frozen blood samples were rapidly thawed on ice and washed twice (223g for $10 \mathrm{~min}$ ) with $5 \mathrm{ml}$ Dulbecco's Modified Eagle Medium (DMEM) supplemented with $2 \%$ fetal bovine serum (FBS).

\section{Alkaline comet assay}

The alkaline comet assay was performed as described by Singh et al. (1988) with minor modifications (Costa et al. 2011). A medium-throughput version 
of the comet assay 12-Gel Comet Assay Unit ${ }^{\mathrm{rm}}$ (Severn Biotech Ltd) was used. Briefly, $5 \mu \mathrm{l}$ of cells suspended on $0.6 \%(\mathrm{w} / \mathrm{v})$ low melting point agarose was dropped onto a frosted slide pre-coated with $1 \%$ normal melting point agarose. Two mini-gels were prepared for each subject in three slides (2x 3 slides), one slide to assess basal DNA damage and two slides to evaluate oxidized purines through enzymatic repair activity. Gels were allowed to set for $2-5$ min at $4^{\circ} \mathrm{C}$ and then immersed in cold lysis solution (2.5 M NaCl, $100 \mathrm{mM} \mathrm{Na}{ }_{2}$ EDTA, $10 \mathrm{mM}$ Tris-base, $0.25 \mathrm{M} \mathrm{NaOH}, \mathrm{pH} 10 ; 1 \%$ Triton X100) for at least $60 \mathrm{~min}$ in the dark at $4^{\circ} \mathrm{C}$. Slides were placed on a horizontal electrophoresis tank, covered with cold alkaline electrophoresis solution ( $1 \mathrm{mM} \mathrm{Na}_{2}$ EDTA, $300 \mathrm{mM} \mathrm{NaOH}, \mathrm{pH} \mathrm{13}$ ), and left for $20 \mathrm{~min}$ in the dark to allow DNA unwinding. Electrophoresis was carried out for $20 \mathrm{~min}$ at $30 \mathrm{~V}$ and $300 \mathrm{~mA}(1.2 \mathrm{~V} /$ $\mathrm{cm}$ ). Subsequently, slides were washed in PBS for 10 $\mathrm{min}$ and rinsed in distilled water for further $10 \mathrm{~min}$. Mini-gels were fixed by immersing slides in $70 \%$ ethanol for $15 \mathrm{~min}$ and in $96 \%$ ethanol for further $15 \mathrm{~min}$. Dried slides were stained with $\mathrm{SYBR}^{\oplus}$ Gold at the dilution recommended by the manufacturer in a bath with agitation. After $30 \mathrm{~min}, \mathrm{SYBR}^{\oplus}$ Gold solution was removed, and slides were rinsed twice with water, left to dry at room temperature and stored until scoring. For scoring, one drop of water was put onto each mini-gel and the slide covered with coverslip. Microscopic analyses were performed blindly by a same reader on a Nikon Eclipse E400 Epi-fluorescence microscope (G2A filter, Nikon C-SH61). The semi-automated image analysis system Comet Assay IV (Perceptive Instruments, UK) was utilized for image capture and analysis. A total of 150 cells were scored for each subject. The \% DNA in the comet tail (\%TDNA) was the DNA damage parameter utilized to describe comet formation.

\section{FPG comet assay}

The comet assay enzyme version was performed as described by Azqueta and Collins (2013). FPG (formamidopyrimidine DNA glycosylase) was the enzyme selected to measure the amount of DNA oxidized purines. Briefly, after lysis, slides for enzyme treatment were washed three times (5 min each) with buffer $\mathrm{F}(0.1 \mathrm{M} \mathrm{KCl}, 0.5 \mathrm{mM}$ $\mathrm{Na}_{2}$ EDTA, $40 \mathrm{mM}$ HEPES, $0.2 \mathrm{mg} / \mathrm{mL}$ BSA, $\mathrm{pH}$
8). Gels were then incubated for $30 \mathrm{~min}$ at $37^{\circ} \mathrm{C}$ with the enzyme or with buffer $\mathrm{F}$ alone. The next steps, unwinding and electrophoresis were performed according to the comet assay classical version described above. Net FPG-sensitive sites were calculated by subtracting the \% TDNA values for the slide incubated with buffer from the score for the slide incubated with enzyme.

\section{Statistical analysis}

A general assessment of the study population was performed through univariate analysis. The distribution within the study groups of sociodemographic and lifestyle factors was evaluated using the Student's t-test for continuous variables and Pearson's chisquare test for categorical variables. All results were assessed for normal distribution using the Kolmogorov-Smirnov goodness-of-fit test and graphic evaluation (histograms, Q-Q plots, P-P plots). Net-FPG was the only parameter that departed significantly from normality, as no improvement was achieved with transformation, the nonparametric test Mann-Whitney U-test was applied to data. Basal DNA damage was determined using the parametric Student's t-test. The influence of factors such as age, gender, smoking habits, body mass index (BMI), respiratory pathologies, allergies, medication intake, and work-related variables (duration and recent exposure) was evaluated by nonparametric and parametric tests. Only a small number of firefighters responded to PPE use question, so due to the lack of responsiveness/dubious answers, this variable was not included in final statistical analyses. KruskalWallis and one-way analysis of variance (ANOVA) were employed for variables with three or more groups. Associations between variables were analyzed by Spearman's rank correlation. A multivariate analysis was also performed, and results confirmed the findings from univariate analysis (data not shown). The level of statistical significance was set at 0.05 . All analyses were performed using the IBM SPSS Statistics V. 21 software ${ }^{\circledR}$.

\section{Results}

Univariate comparisons of effect endpoints by study group are presented in Table 2. Both 
genotoxicity biomarkers were increased in firefighters compared to control subjects. Basal DNA damage was significantly higher in peripheral blood of firefighters compared to controls. With respect to oxidative damage as measured by Net FPG, no significance was found. A significant positive correlation was noted between DNA damage and Net-FPG, confirming the association between these two endpoints. In human biomonitoring studies, it is important to assess the influence of major confounding factors such as gender, age, and smoking habits. The effect of these variables on the DNA damage parameters is shown in Table 2. Regarding gender and smoking habits, no significant effect was detected in either of the endpoints examined. In order to study, the influence of age the population was subdivided into three groups: $<29$ years, $29-38$ years, and $>38$ years. No marked effect was found for controls in either endpoints. However, for firefighters aged between 29 and 38 years, basal DNA damage was significantly higher compared to younger ones, and no significant effect was observed between other age

Table 2. Univariate Comparisons of Effect Endpoints by Study Group.

\begin{tabular}{llcccc}
\hline & & $\begin{array}{c}\text { Controls } \\
\text { (mean } \pm \text { SE) }\end{array}$ & $\begin{array}{c}\text { Firefighters } \\
\text { (mean } \pm \text { SE) }\end{array}$ \\
\hline Basal damage & All & 63 & $6.38 \pm 0.42$ & 60 & $11.23 \pm 0.36^{*}$ \\
& Gender & & & & \\
$\quad$ Female & 10 & $6.15 \pm 0.98$ & 10 & $10.43 \pm 0.94$ \\
& Male & 53 & $6.40 \pm 0.74$ & 50 & $11.39 \pm 0.38$ \\
& Age & & & & \\
& $<29$ & 19 & $7.06 \pm 0.58$ & 20 & $10.30 \pm 0.60$ \\
& $29-38$ & 20 & $6.24 \pm 1.01$ & 20 & $12.49 \pm 0.60^{\#}$ \\
& $>38$ & 24 & $5.90 \pm 0.63$ & 20 & $10.90 \pm 0.64$ \\
& Smoking & & & & \\
& habits & & & & \\
$\quad$ Smoker & 16 & $5.76 \pm 1.04$ & 16 & $11.27 \pm 0.70$ \\
$\quad$ Non-smoker & 47 & $6.76 \pm 0.43$ & 44 & $11.22 \pm 0.42$ \\
& All FPG & 63 & $1.30 \pm 0.16$ & 60 & $2.90 \pm 0.37$ \\
& Gender & & & & \\
$\quad$ Female & 10 & $1.57 \pm 0.48$ & 10 & $2.07 \pm 0.82$ \\
$\quad$ Male & 53 & $1.50 \pm 0.17$ & 50 & $2.58 \pm 0.42$ \\
$\quad$ Age & & & & \\
$\quad<29$ & 19 & $1.19 \pm 0.18$ & 20 & $2.23 \pm 0.66$ \\
$\quad 29-38$ & 20 & $1.78 \pm 0.34$ & 20 & $2.67 \pm 0.72$ \\
$\quad>38$ & 24 & $1.54 \pm 0.30$ & 20 & $2.57 \pm 0.59$ \\
$\quad$ Smoking & & & & \\
habits & & & & \\
$\quad$ Smoker & 16 & $1.57 \pm 0.40$ & 16 & $2.95 \pm 0.80$ \\
$\quad$ Non-smoker & 47 & $1.49 \pm 0.17$ & 44 & $2.58 \pm 0.42$ \\
\hline
\end{tabular}

SE-standard error deviation.

${ }^{*} p>0.05$, significantly different from control group.

${ }^{\#} p>0.05$, significant difference with regard to age class $<29$ among exposed individuals.

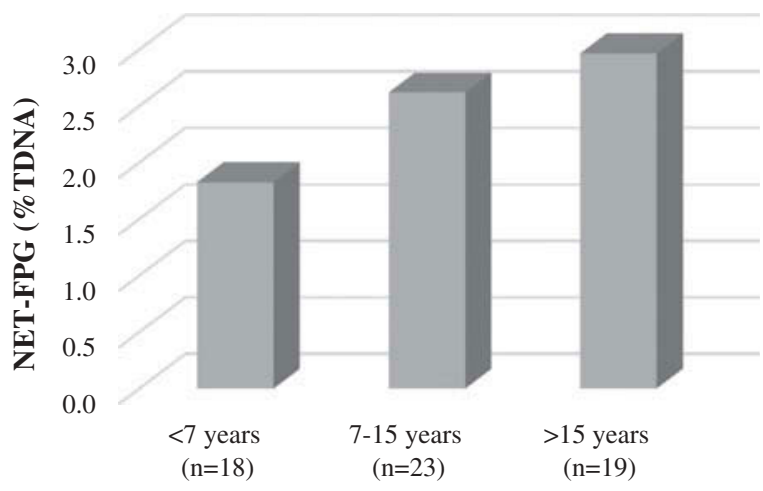

Duration of exposure (years of firefighting)

Figure 1. Effect of duration of exposure (classes) on NET-FPG parameter (n-number of firefighters).

groups. No marked influence was detected concerning other confounding factors including BMI, medication intake and the presence of respiratory disease and allergies. Work-related variables such as years of activity (time of exposure) and hr recent exposure were also studied. The hr spent in recent firefighting activities exerted no marked influence on genotoxic endpoints. To determine the effect of years as firefighters, this variable was categorized into three groups: $<7$ years, $7-15$ years, and $>15$ years. No significant influence was observed for the endpoints studied. However, regarding oxidative DNA damage (Net-FPG), data demonstrated a numerical rise with increasing years of firefighting activity (Figure 1).

\section{Discussion}

Data obtained in this study showed a significant elevation in basal firefighter DNA damage compared to controls. Net-FPG was also numerically increased in firefighters; however, statistical significance was not reached. Our findings are in agreement with available data supporting the induction of oxidative stress and DNA damage in response to wood smoke exposure as evidenced by both in vivo human and human cell culture experiments (Barregard et al., 2006; Adetona et al., 2013; Corsini et al., 2013). Danielsen et al. (2008) found no marked association between short-term experimental exposure to wood smoke and oxidative damage as measured by comet assay in peripheral blood mononuclear cells of healthy human volunteers. However, urinary levels of 8-oxoGua 
and expression levels of 8-oxoguanine glycosylase (OGG1) base repair enzyme, which removes 8oxoGua from DNA, were elevated in some subjects after exposure to wood smoke but not after exposure to clean air. Danielsen et al (2008) suggested that the lack of association might be attributed to increased DNA repair activity after exposure to wood smoke. Subsequently, Danielsen et al (2009; 2011) noted observed a concentration-dependent rise in the formation of strand breaks and FPG sites in human A549 lung and THP-1 monocytic cell lines in response to wood smoke particles exposure. Muala et al (2015) in a recent genotoxicity investigation of wood smoke particles demonstrated that these particles produced death and DNA damage in RAW264.7 macrophage cell line. Other biomarkers of oxidative damage were tested in human controlled exposure studies with positive results (Barregard et al., 2008) confirming that the production of reactive species induced by exposure to wood smoke may play a critical role in the genotoxicity mediated by wood smoke and its main components (Danielsen et al., 2011).

Despite these positive findings, to our knowledge, only two apparent studies were available that examined the genotoxic effects of exposure to wood smoke in wildland firefighters. Adetona et al. (2013) observed an overall increase in urinary 8-oxo-dG level (unadjusted geometric mean) in wildland firefighters compared to healthy individuals in occupational or general population. Further, Gaughan et al. (2014) found among firefighters a positive association between wood smoke exposure, as measured by urinary levoglucosan levels, and oxidative stress scores (average z-score for urinary 8-isoprostane and 8-hydroxy2'-deoxyguanosine).

No significant differences were found in the present study regarding possible confounders, namely gender, smoking habits, BMI, medication intake, and the presence of respiratory diseases or allergies. Firefighters aged between 29 and 38 years old displayed a significant elevation in basal DNA damage compared to firefighters younger than 29 years of age. The influence of age on comet assay parameters is not clear (Møller et al., 2000). However, it is known a positive association between age and effect biomarkers related to a progressive rise in spontaneous chromosome instability and loss of efficiency in DNA repair mechanisms was indicated by Kirsh-Volders et al. (2006). No other significant differences were detected between age groups. Similar means of basal DNA damage were found for younger and older classes, since no significant differences were noted in duration spent firefighting between age groups. One possible explanation may involve the work task and proximity to fire; however, no information in this regard was collected to test this hypothesis. Adetona et al. (2013) found that subjects who had worked as wildland firefighters for longer than two years had higher but steady levels of urinary 8-oxo-dG. Although not significant, a numerical rise in levels of Net-FPG with exposure duration (years of activity) was detected in $88 \%$ of the subjects enrolled that worked for more than 2 years.

Between January and October of 2014, 1,062 fires occurred burning a total area of 19696 ha. Comparing the values of 2014 with mean values of the last 10 years (2004-2013), there was a 66\% decrease in number of fires and $82 \%$ less of burnt area (ICNF, 2014). The summer of 2014 was one of the coldest since 1989 (IPMA, 2014), and this atypical scenario in Portugal may have an influence in the results obtained.

Our study has a few limitations: a) reduced population; b) self-reporting questionnaire; c) lack of information regarding detoxification measures after firefighting such as drinking milk; and d) sampling time, period between exposure and sampling may have allowed a small window to DNA repair. To our knowledge, the present study is the first in Portugal to report data on levels of both basal and oxidative DNA damage of wildland firefighters during fire season.

\section{Conclusions}

Data obtained in this study indicate that wildland firefighting and wood smoke exposure are associated with an increased level of DNA damage suggesting a potential adverse health risk. In addition, firefighters displayed higher oxidative damage compared to controls, namely as evidenced by higher oxidized purines (including 8oxo-dG) levels. However, these results need to be carefully interpreted, mostly due to the limited size 
of our population. Hence, further studies with larger populations are needed to confirm these findings complemented with biomarkers of exposure. Although the measurement of potential biomarkers of exposure to wood smoke or its metabolites may help to measure actual exposure, effect biomarkers estimates also provide knowledge on the potential impact of the exposure on macromolecules such as DNA. Taken together, these biomarkers provide information on compound toxicity and underlying mechanisms. Data from this study may offer the support needed to implement effective measures in order to protect firefighters health, including regular monitoring and surveillance activities, such as medical surveillance, good practice campaigns focused on a more effective use of PPE, training programs, and implementation of written policies and procedures.

\section{Funding}

The work of CC and SC was supported by the Portuguese Foundation for Science and Technology (FCT) under the grants SFRH/BPD/96196/2013 (CC) and SFRH/BPD/ $100948 / 2014$ (SC).The authors would also like to acknowledge the contribution of the COST action CA15132 to this study.

\section{ORCID}

Vanessa Moraes de Andrade (D) http://orcid.org/0000-0002$8474-4482$

\section{References}

Adetona, O, Zhang, J. J., Hall, D. B., Wang, J-S., Vena, J. E. and Naeher, L. P. 2013. Occupational exposure to woodsmoke and oxidative stress in wildland firefighters. Sci. Total Environ. 449: 269-275.

Adetona, O., Reinhardt, T. E., Domitrovich, J., Broyles, G., Adetona, A. M., Kleinman, M. T., Ottmar, R. D., and Naeher, L. P. 2016. Review of the health effects of wildland fire smoke on wildland firefighters and the public. Inhal Toxicol 28: 95-139.

Ahlborg, U. G., Becking, G. C., Birnbaum, L. S., Brouwer, A. A., Derks, H. J. G. M., Feeley, M., and Safe, S. H. 1994. Toxic equivalency factors for dioxin-like PCBs: Report on WHO-ECEH and IPCS consultation. Chemosphere 28: 1049-1067.

Akor-Dewu, M. B., El Yamani, N., Bilyk, O., Holtung, L., Tjelle, T. E., Blomhoff, R., and Collins, A. R. 2014. Leucocytes isolated from simply frozen whole blood can be used in human biomonitoring for DNA damage measurement with the comet assay. Cell Biochem. Funct. 32: 299-302.

Al-Salmani, K., Abbas, H. H.K., Schulpen, S., Karbaschi, M., Abdalla, I., Bowman, K. J., So, K. K., Evans, M. D., Jones, G. D. D., Godschalk, R. W., and Cooke, M. S. 2011. Simplified method for the collection, storage, and comet assay analysis of DNA damage in whole blood. Free Radic. Biol. Med. 51: 719-725.

Austin, C. C., Wang, D., Ecobichon, D. J., and Dussault, G. 2001. Characterization of volatile organic compounds in smoke at municipal structural fires. J. Toxicol. Environ. Health A 63: 437-458.

Azqueta, A., and Collins, A. R. 2013. The essential comet assay: A comprehensive guide to measuring DNA damage and repair. Arch. Toxicol. 87: 949-968.

Barregard, L., Sällsten, G., Gustafson, P., Andersson, L., Johansson, L., Basu, S., and Stigendal, L. 2006. Experimental exposure to wood-smoke particles in healthy humans: Effects on markers of inflammation, coagulation, and lipid peroxidation. Inhal. Toxicol. 18: 845-853.

Barregard, L., Sällsten, G., Andersson, L., Almstrand, A.-C., Gustafson, P., Andersson, P., and Olin, A-C. 2008. Experimental exposure to wood smoke: Effects on airway inflammation and oxidative stress. Occup. Environ. Med. 65: 319-324.

Budd, G. M., Brotherhood J. R., Hendrie, A. L., Jeffery, S. E., Beasley, F. A., Costin, B. P., Zhien, W., Baker, M. M., Cheney, N. P., and Dawson, M. P. 1997. Project Aquarius 5. Activity distribution, energy expenditure, and productivity of men suppressing free-running wildland fires with hand tools. Int. J. Wildland Fire 7: 105-118.

Campos, C. F., Júnior, E. O. D. C., Souto, H. N., Sousa, E. D. F., and Pereira, B. B. 2016. Biomonitoring of the environmental genotoxic potential of emissions from a complex of ceramic industries in Monte Carmelo, Minas Gerais, Brazil, using Tradescantia pallida. J. Toxicol. Environ. Health A 79: 123-128.

Collins, A. R. 2004. The comet assay for DNA damage and repair. Molecular Biotechnology 26: 249-261.

Collins, A., Koppen, G., Valdiglesias, V., Dusinska, M., Kruszewski, M., Møller, P., Rojas, E., Dhawan, A., Benzie, I., and Coskun, E. 2014. The comet assay as a tool for human biomonitoring studies: The ComNet project. Mutat. Res. Rev. Mutat Res. 759: 27-39.

Cooke, G M., 2014 Biomonitoring of human fetal exposure to envirinmetal chemicals in early pregnancy. J. Toxicol. Environ. Health B 17: 205-224.

Corsini, E., Budello, S., Marabini, L., Galbiati, V., Piazzalunga, A., Barbieri, P., Cozzutto, S., Marinovich, M., Pitea, D., and Galli, C. L. 2013. Comparison of wood smoke PM2. 5 obtained from the combustion of FIR and beech pellets on inflammation and DNA damage in A549 and THP-1 human cell lines. Arch. Toxicol 87: 2187-2199.

Costa, S., Pina, C., Coelho, P., Costa, C., Silva, S., Porto, B., Laffon B. and Teixeira, J. P. 2011. Occupational exposure 
to formaldehyde: Genotoxic risk evaluation by comet assay and micronucleus test using human peripheral lymphocytes. J. Toxicol. Environ. Health A 74: 1040-1051.

Costa, S., Carvalho, S., Costa, C., Coelho, P., Silva, S., Santos, L. S., Gaspar, J. F., Porto, B., Laffon, B., and Teixeira, J. P. 2015. Increased levels of chromosomal aberrations and DNA damage in a group of workers exposed to formaldehyde. Mutagenesis 30: 463-473.

Danielsen, P. H., Bräuner, E. V., Barregard, L., Sällsten, G., Wallin, M., Olinski, R., Rozalski, R., Møller, P., and Loft, S. 2008. Oxidatively damaged DNA and its repair after experimental exposure to wood smoke in healthy humans. Mutat. Res. 642: 37-42.

Danielsen, P. H., Loft, S., Kocbach, A., Schwarze, P. E., and Møller, P. 2009. Oxidative damage to DNA and repair induced by Norwegian wood smoke particles in human A549 and THP-1 cell lines. Mutat. Res. 674: 116-122.

Danielsen, P. H., Møller, P., Jensen, K. A., Sharma, A. K., Wallin, H., Bossi, R., Autrup, H., Mølhave, L., Ravanat, JL., and Briedé, J. J. 2011. Oxidative stress, DNA damage, and inflammation induced by ambient air and wood smoke particulate matter in human A549 and THP-1 cell lines. Chem. Res Toxicol. 24: 168-184.

Dubick, M. A., Carden, S. C., Jordan, B. S., Langlinais, P. C., and Mozingo, D. W. 2002. Indices of antioxidant status in rats subjected to wood smoke inhalation and/or thermal injury. Toxicology 176: 145-157.

Durán, S., Reisen, F., and Rideout, K. 2014. Evidence Review: Wildfire smoke and public health risk. BC Centre for Disease Control, Vancouver BC.

Elliott, C. T. 2014. Guidance for BC Public Health Decision Makers During Wildfire Smoke Events. BC Center for Disease Control.

Fahs, C. A, Yan, H., Ranadive, S., Rossow, L. M., Agiovlasitis, S., Echols, G., Smith, D., Horn, G. P., Rowland, T., and Lane, A. 2011. Acute effects of firefighting on arterial stiffness and blood flow. Vasc. Med. 16: 113-118.

Fahy, R. F., and National Fire Protection Association. 2005. US firefighter fatalities due to sudden cardiac death, 19952004: National Fire Protection Association Quincy, Mass.

Gaughan, D. M., Cox-Ganser, J. M., Enright, P. L., Castellan, R. M., Wagner, G. R., Hobbs, G. R., Bledsoe, T. A., Siegel, P. D., Kreiss, K., and Weissman, D. N. 2008. Acute upper and lower respiratory effects in wildland firefighters. $J$. Occup. Environ. Med. 50: 1019-1028.

Gaughan, D. M., Siegel, P. D., Hughes, M. D., Chang, C.-Y., Law, B. F., Campbell, C. R., Richards, J. C., Kales, S. F., Chertok, M., and Kobzik, L. 2014. Arterial stiffness, oxidative stress, and smoke exposure in wildland firefighters. Am. J. Ind. Med. 57: 748-756.

Golka, K., and Weistenhöfer, W. 2008. Fire fighters, combustion products, and urothelial cancer. J. Toxicol. Environ. Health B 11: 32-44.

Hejl, A. M., Adetona, O., Diaz-Sanchez, D., Carter, J. D., Commodore, A. A., Rathbun, S.L. and Naeher LP. 2013. Inflammatory effects of woodsmoke exposure among wildland firefighters working at prescribed burns at the
Savannah River Site, SC. J. Occup. Environ. Hyg. 10: $173-180$

IARC (International Agency for Research on Cancer). 2010. Painting, firefighting and shiftwork. IARC Monogr. Eval. Carcinogen. Risks Hum. 98. Lyon, France: World Health Organization.

ICNF (Instituto da Conservação da natureza e das Florestas). 2013. IFN6-Áreas dos usos do solo e das espécies florestais de Portugal continental. Resultados preliminares. Instituto da Conservação da Natureza e das Florestas Lisboa.

ICNF (Instituto da Conservação da natureza e das Florestas). 2014. Relatório provisório de Incêndios Florestais 2014-01 Janeiro a 15 de Outubro. Instituto da Conservação da Natureza e das Florestas.

INE (Instituto Nacional de Estatística). 2015. Bombeiros (N. ${ }^{\circ}$ ) por Localização geográfica (NUTS - 2002), Sexo e Nível de escolaridade; Anual. Instituto Nacional de Estatística.

(IPMA Instituto Português da Meteorologia e Atmosfera). 2014. Boletim Meteriológico Sazonal - Verão de 2014. edited by Divisão Clima e Alterações Climáticas. available at http://www.ipma.pt/pt/(consulted on September 2016)

Jensen, A., Karottki, D. G., Christensen, J. M., Bønløkke, J. H., Sigsgaard, T., Glasius, M., Loft, S. and Møller, P. 2014. Biomarkers of oxidative stress and inflammation after wood smoke exposure in a reconstructed Viking Age house. Environ. Mol. Mutagen. 55: 652-661.

Kirsch-Volders, M., Mateuca, R. A., Roelants, M., Tremp, A., Zeiger, E., Bonassi, S., Holland, N., Chang, W. P., Aka, P. V., and DeBoeck, M. 2006. The effects of GSTM1 and GSTT1 polymorphisms on micronucleus frequencies in human lymphocytes in vivo. Cancer Epidemiol. Biomarkers Prev. 15:1038-1042.

Lee, T-S., Liu, Y-J., Tang, G-J., Yien, H.-W., Wu, Y-L., and Kou, Y. R. 2008. Wood smoke extract promotes both apoptosis and proliferation in rat alveolar epithelial type II cells: The role of oxidative stress and heme oxygenase-1. Crit. Care Med. 36: 2597-2606.

Leonard, S. S., Wang, S., Shi, X., Jordan, B. S., Castranova, V., and Dubick, M. A. 2000. Wood smoke particles generate free radicals and cause lipid peroxidation, DNA damage, NFkappaB activation and TNF-alpha release in macrophages. Toxicology 150: 147-157.

Leonard, S. S., Castranova, V., Chen, B. T., Schwegler-Berry D., Hoover, M., Piacitelli, C., and Gaughan, D. M. 2007. Particle size-dependent radical generation from wildland fire smoke. Toxicology 236: 103-113.

Links, J. M., Kensler, T. W., and Groopman, J. D. 1995. Biomarkers and mechanistic approaches in environmental epidemiology. Annu. Rev Publ. Health 16: 83-103.

Liu, P. L., Chen, Y. L., Chen, Y. H., Lin, S. J., and Kou, Y. R. 2005. Wood smoke extract induces oxidative stressmediated caspase-independent apoptosis in human lung endothelial cells: Role of AIF and EndoG. Am. J. Physiol. Lung Cell. Mol. Physiol. 289: L739-L749.

Melius, J. 2000. Occupational health for firefighters. Occup. Med. 16: 101-108. 
Miranda, A. I., Martins, V., Cascão, P., Amorim, J. H., Valente, J., Tavares, T., Borrego, C., Tchepel, O., Ferreira, A. J., and Cordeiro, C. R. 2010. Monitoring of firefighters exposure to smoke during fire experiments in Portugal. Environ. Int. 36:736-745.

Miranda, A. I., Martins, V., Cascão, P., Amorim, J. H., Valente, J., Borrego, C., Ferreira, A. J., Cordeiro C. R., Viegas, D. X., and Ottmar R. 2012. Wildland smoke exposure values and exhaled breath indicators in firefighters. $J$. Toxicol. Environ. Health A 75: 831-843.

Møller, P., Knudsen, L. E., Loft, S., and Wallin, H. 2000. The comet assay as a rapid test in biomonitoring occupational exposure to DNA-damaging agents and effect of confounding factors. Cancer Epidemiol. Biomarkers Prev. 9:1005-1015.

Muala, A., Rankin, G., Sehlstedt, M., Unosson, J., Bosson, J. A., Behndig, A., Pourazar, J., Nyström, R., Pettersson, E., Bergvall, C., Westerholm, R., Jalava, P.I., Happo, M. K., Uski, M., Hirvonen, M.-R., Kelly, F. J., Mudway, I. S., Blomberg, A., Boman, C. and Westerholm, R. 2015. Acute exposure to wood smoke from incomplete combustionindications of cytotoxicity. Part. Fibre Toxicol. 29: 12-33.

Naeher, L. P., Brauer, M., Lipsett, M., Zelikoff, J. T., Simpson, C. D., Koenig, J. Q., and Smith, K. R. 2007. Woodsmoke health effects: A review. Inhal Toxicol 19: 67-106.

Neri, M., Milazzo, D., Ugolini, D., Milic, M., Campolongo, A., Pasqualetti, P., and Bonassi, S.2015. Worldwide interest in the comet assay: A bibliometric study. Mutagenesis 30:155-163.

Oliveira, B. F. A., Chacra, A. P. M., Frauches, T. S., Vallochi, A., and Hacon, S. 2014. A curated review of recent literature of biomarkers used for assessing air pollution exposures and effects in humans. J. Toxicol. Environ. Health $B$ 17: $369-410$.

Oliveira, M., Slezakova, K., Alves, M. J., Fernandes, A., Teixeira, J.P., Delerue-Matos, C., Pereira, M. D., and Morais S. 2016. Firefighters' exposure biomonitoring: Impact of firefighting activities on levels of urinary monohydroxyl metabolites. Int. J. Hyg. Environ. Health 219: 857-866.

Order No. 3974/2013 of February13, 2013. Regulation of technical specifications vehicles and operating equipment of fire brigades. DR II series no. 53 of February 13, 2013, Portuguese Republic.

Order no. 4958/2014 of April 8, 2014. Amendment to Order No. 3974/2013 of February 13, 2013. DR II series no. 69 of April 8, 2014, Portuguese Republic.
Park, M. S., Cancio, L. C., Jordan, B. S., Brinkley, W. W., Rivera, V. R., and Dubick, M. A. 2004. Assessment of oxidative stress in lungs from sheep after inhalation of wood smoke. Toxicology 195: 97-112.

Pereira, M. G., Aranha, J., and Amraoui, M. 2014. Land cover fire proneness in Europe. Forest Systems 23:598-610.

Ramos, C., Pedraza-Chaverri, J., Becerril, C., Cisneros, J., González-Ávila, G., Rivera-Rosales, R., Sommer, B., Medina-Campos, O. N., and Montano, M. 2013. Oxidative stress and lung injury induced by short-term exposure to wood smoke in guinea pigs. Toxicol. Mech. Meth. 23: 711-722.

Reinhardt, T. E., and Ottmar, R. D. 2000. Smoke exposure at western wildfires. US Department of Agriculture, Forest Service, Pacific Northwest Research Station. Roszkowski, K., Jozwicki, W., Blaszczyk, P., Mucha-Malecka A., and Siomek, A. 2011. Oxidative damage DNA: 8-oxoGua and 8-oxodG as molecular markers of cancer. Med. Sci. Monit. 17: CR329-CR333.

Ruby, B.C., Shriver, T. C., Zderic, T. W., Sharkey, B. J., Burks. C, and Tysk, S. 2002. Total energy expenditure during arduous wildfire suppression. Med. Sci. Sports Exerc. 34: 1048-1054.

Schmuck, G., SanMiguel-Ayanz, J., Camia, A., Durrant, T. H., Boca, R., Libertá, G.,Petroliagkis, T., Di Leo, M., Rodriguez-Aseretto, D., and Boccacci F. 2014. Forest Fires in Europe, Middle East and North Africa 2013. Joint Report of Joint Report Center and DirectorateGeneral Environment

Singh, N. P., McCoy, M. T., Tice, R. R., and Edward L Schneider. 1988. A simple technique for quantitation of low levels of DNA damage in individual cells. Exp. Cell Res. 175: 184-191.

Slaughter, J. C., Koenig, J. Q., and Reinhardt, T.E. 2004. Association between lung function and exposure to smoke among firefighters at prescribed burns. J. Осcup. Environ. Hyg. 1: 45-49.

Stefanidou, M., Athanaselis, S., and Spiliopoulou, C. 2008. Health impacts of fire smoke inhalation. Inhal. Toxicol. 20:761-766.

Swiston, J. R., Davidson, W., Attridge, S., Li, G. T., Brauer, M., and van Eeden, S. F. 2008. Wood smoke exposure induces a pulmonary and systemic inflammatory response in firefighters. Eur. Respir. J. 32:129-138.

Zelikoff, J. T., Chen, L. C., Cohen, M. D., and Schlesinger, R. B. 2002. The toxicology of inhaled woodsmoke. J. Toxicol. Environ. Health B 5: 269-282. 